\title{
In vitro and in vivo studies of cytotoxic effects of $\mathrm{FeSO}_{4}$ nanoparticles
}

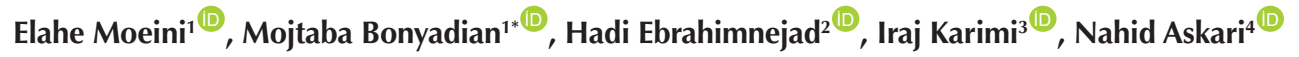 \\ 'Department of Health and Food Quality Control, Faculty of Veterinary Medicine, Shahrekord University, Shahrekord, Iran \\ ${ }^{2}$ Department of Food Hygiene and Public Health, Faculty of Veterinary Medicine, Shahid Bahonar University of Kerman, \\ Kerman, Iran \\ ${ }^{3}$ Department of Pathology, Faculty of Veterinary Medicine, Shahrekord University, Shahrekord, Iran \\ ${ }^{4}$ Research Department of Biotechnology, Institute of Sciences and High Technology and Environmental Sciences, Graduate \\ University of Advanced Technology, Kerman, Iran
}

*Corresponding Author: Mojtaba Bonyadian, Department of Health and Food Quality Control, Faculty of Veterinary Medicine, Shahrekord University, Shahrekord, Iran. Tel: +989131811856, Fax: +9838 32324427, Email: boniadian@sku.ac.ir

\begin{abstract}
Background and aims: Using iron as a food additive usually causes undesirable sensory changes and side effects in humans. In this study, we made iron (Fe) nanoparticles (NPs) and studied the cytotoxicity of $\mathrm{FeSO}_{4}$ bulk and NPs on HT-29 cells and different doses of these particles on rat intestine.

Methods: Particle size of nanoscale was achieved by mechanical technique. Iron particles were characterized using scanning electron microscopy (SEM) and transmission electron microscopy (TEM). The effect of iron particles with different concentrations $(6.25,3.125$, and $1.57 \mathrm{mM} / \mathrm{mL}$ ) on the colon cell line was performed using the MTT assay at 24,48 , and 72 hours. Apoptosis and necrosis of the cells were assessed using Annexin V-FITC staining and propidium iodide (PI) at $24 \mathrm{~h}$. In an in vivo study, Taftoon bread was produced from fortified wheat flour with $\mathrm{FeSO}_{4}$ bulk and NPs, which are recommended in human diet $(9,18$, and $27 \mathrm{mg}$ of elemental iron/kg flour). Wistar rats were fed daily with fortified bread for 21 days and their colon and small intestine were then evaluated histopathologically. Statistical analyses were performed using SPSS 22.0 software by chi-square test.

Results: The synthesized $\mathrm{FeSO}_{4} \mathrm{NPs}$ were smaller than $100 \mathrm{~nm}$, and they had more adverse effects on the viability of the HT-29 cells compared to the bulk- $\mathrm{FeSO}_{4}$ at 72 hours. Flow cytometric study showed that the early apoptosis of cells by the bulk form was more than the NPs, but at the low concentration $(1.57 \mathrm{mM} / \mathrm{mL})$, the NPs induced more necrosis than the bulk particles $(P=0.063)$. The survival rate of cells facing all concentrations of NPs and bulk- $\mathrm{FeSO}_{4}$ decreased dose dependently $(P=0.075)$. In vivo results revealed that there were no pathological changes in rats' intestinal tissues.

Conclusion: The bulk and NPs of iron have adverse effects on the HT-29 cells, but no histopathological changes were seen on rats' intestinal cells.

Keywords: Iron nanoparticles, Intestinal cell culture, Histopathology, Cytotoxicity
\end{abstract}

Received: 4 August 2019, Accepted: 9 October 2019, ePublished: 30 March 2021

\section{Introduction}

Despite the comprehensive application of nanoparticles (NPs) in foods, such as improving flavour and texture, increasing shelf life, enhancing dietary value, the small size of these nanoparticles, i.e. less than $100 \mathrm{~nm}$, and the possibility of their attachment to vital body structures and causing toxic effects, stay a source of concern among scientists, as reflected in the research undertaken (1-12). Moreover, NPs' properties can affect their toxicity to biological systems such as cell culture (13-15). Therefore, determination of a suitable dose of NPs in cytotoxicity assessments can influence their toxic impacts (16). In addition, global investments in nanotechnology research have dramatically increased $(17,18)$ and numerous cytotoxicity studies are still ongoing to address the growing concern over the toxic effects of NPs on human health $(15,19)$. As the most abundant metal in the environment and an important and well-known micronutrient, iron is vital for biochemical reactions in the body and for producing blood cells. Iron deficiency is also globally prevalent as the most widespread nutritional disorder (20). In the event that the oral iron supplied is insufficient to make red blood cells, the body first uses its reserves, including the iron stored in the liver, leading to iron deficiency anemia if the condition is not treated. The improper distribution of iron-enriched foods, the delayed beginning of supplementation, the insufficient daily dose of prescribed iron, and malnutrition are factors that contribute substantially to iron deficiency anemia. Today, iron deficiency anemia is a prevalent and

(C) 2021 The Author(s); Published by Shahrekord University of Medical Sciences. This is an open-access article distributed under the terms of the Creative Commons Attribution License (http://creativecommons.org/licenses/by/4.0), which permits unrestricted use, distribution, and reproduction in any medium, provided the original work is properly cited. 
widespread nutritional disorder during pregnancy in most countries, including Iran, and a major risk factor for increasing the maternal and neonatal mortality and the prevalence of low birth weight and premature birth (2123). Enriching foods such as bread with iron supplements is an effective and inexpensive strategy for controlling and preventing disorders associated with iron deficiency or iron deficiency compensation; nevertheless, this strategy can cause problems such as changing the taste and color of the food or gastrointestinal tract complications (2426). Iron compounds with the highest bioavailability can cause undesirable sensory changes as they are strongly attracted to nutrient components. The optimal iron compound selected for food enrichment should have the highest relative bioavailability, be cost-effective, and does not cause unacceptable sensory changes in taste, color, and texture of the food. Divalent iron sulfate is a compound with the chemical formula of $\mathrm{FeSO}_{4}$, which is widely used as a water-soluble iron enrichment agent for enriching flour owing to its cost-effectiveness. $\mathrm{FeSO}_{4}$ is a generally recognized as safe (GRAS) compound that is recommended for low-extraction flour enrichment. $\mathrm{FeSO}_{4}$ salt with the highest bioavailability among iron compounds is a peroxide whose ferrous ions are converted into ferric ions during oxidation. Ferric compounds can change the color of food products into brown, and are less absorbed in the intestine due to its insolubility. Its large particles also cause fairly acceptable darkness in the flour and black spots in the bread (27-30). Given the extensive use of iron as a food additive, the current research aimed to discover data on ways to reduce undesirable sensory modifications and side effects induced by their bulk form by studying the cytotoxicity of nanosized and bulk iron particles to HT-29 cells and the impacts of separate doses of these particles on the intestine of rats.

\section{Materials and Methods}

\section{Synthesis of NPs and Characterization of Particles}

A planetary ball mill made by Fritsch Pulverisette 6 was used to physically synthesize $87 \%$ pure $\mathrm{FeSO}_{4}$ as NPs. To prepare these NPs, the bulk $\mathrm{FeSO}_{4}$ was poured into the machine and milled at 200 rph for 15 hours with a ballto-powder weight ratio of 10:1 (31).

The particle shape, size and mean diameter of NPs was observed by scanning electron microscopy (SEM; KYKYEM3200, China) and transmission electron microscopy (TEM; Philips CM 10, Eindhoven, The Netherlands).

\section{In vitro evaluation of the toxicity of iron NPs}

The human intestinal HT-29 cell line can be a good model for cytotoxicity assessments of different materials for cells (32). The human colon cell (HT-29) line was procured from the National Cell Bank of Pasteur Institute, Tehran, Iran. These cells were grown on RPMI 1640 Medium (Roswell Park Memorial Institute medium, Gibco,
USA) along with $100 \mathrm{U} / \mathrm{ml}$ of penicillin, $100 \mu \mathrm{g} / \mathrm{mL}$ of streptomycin, and 10\% fetal bovine serum (FBS, Gibco, USA), and incubated at $37^{\circ} \mathrm{C}$ in an atmosphere containing $5 \% \mathrm{CO}_{2}$ (33). These cells were cultivated as single layers in a flask. The culture medium was substituted three times a week, and the cells were isolated with trypsinase and passaged at $80 \%-90 \%$ confluence. The cells were ultimately counted and cultured in 96-well plates.

\section{Cell Viability Assay}

The MTT assay is a quantitative and staining test based on the reduction of the water-soluble yellow salt of 3-(4.5dimethylthiazol-2yl)-2.5 diphenyl tetrazolium bromide and the formation of insoluble dark-blue formazan crystals in water. The MTT reduction occurs only in viable cells by the mitochondrial enzyme of succinate dehydrogenase. The cells viability is therefore measured with the MTT assay. Colon cells $\left(1 \times 10^{4}\right.$ cells/well $)$ were fully grown in 24 hours on the 96-well plates in RPMI 1640 medium. After reaching $80-90 \%$ cell confluence, the supernatant was replaced with a new medium containing different doses of nanosized and bulk iron particles, i.e. 6.25, 3.125, and $1.56 \mathrm{mM} / \mathrm{mL}$. The selected doses were based on the previous studies $(34,35)$, and the test was performed with three interactions. After 24, 48, and 72 hours, $10 \mu \mathrm{L}$ of filter-sterilized MTT ( $5 \mathrm{mg} / \mathrm{mL}$ in PBS, Melford) was added to each well and incubated for 4 hours at $37^{\circ} \mathrm{C}$. In the next step, the Formazan crystals produced were dissolved into each well by adding $100 \mu$ of DMSO (Roth, Germany), and the produced stain was read at $570 \mathrm{~nm}$ using an ELISA reader. The viability was calculated using the relative absorbance and expressed as the percentage of that of the control sample (36).

Apoptosis and necrotic cells were evaluated by using Annexin V staining and Propidium iodide (PI). The cells were cultivated for 24 hours with distinct levels (6.25, 3.125 , and $1.56 \mathrm{mM} / \mathrm{mL}$ ) of the $\mathrm{FeSO}_{4}$ bulk and NPs. Cells were detached and stained with PE-Annexin V and PI, based on the manufacturer's protocol of Annexin V apoptosis detection kit I (BD Pharmingen ${ }^{\mathrm{TM}}$ ) and analyzed by flow cytometry (Partec, Germany).

\section{Production of iron-enriched bread}

Wheat flour was first obtained from Danesayan Factory ${ }^{\mathrm{TM}}$ in Kerman, Iran, and mixed with a certain amount of iron NPs and bulk iron. After adding the yeast (Saccharomyces cerevisiae, PTCC 5080), 55\%-60\% water and 1\%-2\% salt, bread containing 9, 18, and $27 \mathrm{mg}$ of iron/ $\mathrm{kg}$ of flour was prepared (37).

\section{In vivo evaluation of the toxicity of iron NPs Preparation and grouping of animals}

A total of 49 Wistar rats (Rattus norvegicus) weighing $280 \pm 20 \mathrm{~g}$ were procured from the national laboratory animal house in Kerman, Iran. The animals were kept in 
polyvinyl carbonate cages for one week in an animal house at $22 \pm 2^{\circ} \mathrm{C}$ and humidity of $55 \pm 5 \%$ and in $12: 12$ lightdark cycles (38). They had free access to food and water. All the ethical principles of conducting animal research were observed. The rats were then randomly divided into seven groups ( $\mathrm{n}=7$ in each), including a control group. Three groups treated daily with bread enriched with bulk iron containing 9,18 , and $27 \mathrm{mg}$ of iron $/ \mathrm{kg}$ of flour and, three groups treated daily with bread enriched with iron NPs with the same dose for 21 days (39-41). These groups were carefully examined for emerging clinical symptoms. After the period of treatment, rats were euthanized using $80 \mathrm{mg} / \mathrm{kg}$ ketamine and $2.5 \mathrm{mg} / \mathrm{kg}$ Acepromazine IV and histological samples were taken.

\section{Histopathology}

Samples ultimately were taken from the colon and small intestine of the rats, and were fixed with $10 \%$ formalin. Hematoxylin and eosin (H\&E) stain was used to examine the pathological changes.

\section{Statistical analysis}

The data were analyzed in SPSS 22 software by chi-square test, and $P<0.05$ was considered a significant difference. The data obtained from histopathological studies were also investigated and expressed using descriptive statistics.

\section{Results}

\section{Characterization of particles}

The particles' morphology was nanospheres, and the mean particle size decreased to less than $100 \mathrm{~nm}$ after nanonization (Figure 1).

\section{Cell proliferation and metabolic activity}

The results showed that HT-29 cells metabolic activity in all the three concentration, except for $6.25 \mathrm{mM} / \mathrm{mL}$ of bulk particles, decreased after 72 hours in a dose- and time-dependent manner, so that cell viability at different concentrations of bulk $\mathrm{FeSO}_{4}(1.57,3.125$, and $6.25 \mathrm{mM} /$ $\mathrm{mL}$ ) was $100 \%, 96 \%$, and $73.7 \%$ at 72 hours, respectively. However, the survival rate of cells facing NPs was $66.9 \%$, $87.4 \%$, and $59.7 \%$. The cell viability decreased by approximately $40.3 \%$ of bulk $\mathrm{FeSO}_{4}$ at high concentration $(6.25 \mathrm{mM} / \mathrm{mL})$ in the colon cell line.

Furthermore, the results showed that cell viability decreased from $89.2 \%$ to $73.7 \%$ and from $77.4 \%$ to $59.7 \%$ by bulk and NPs, respectively, at high concentration $(6.25 \mathrm{mM} / \mathrm{mL})$ in a time-dependent manner.

The statistical analyses revealed that there were no significant differences among control and treatment groups $(P=0.063)$. Moreover, no significant difference was seen between groups treated with bulk Fe and Fe NPs $(P=0.75)$ (Figure 2).

Furthermore, flow cytometry determined the amount of necrotic and apoptotic cells. The maximum amount of necrotic cells was associated with a $1.57 \mathrm{mM} / \mathrm{mL}$ concentration of bulk $\mathrm{FeSO}_{4}$. However, the flow cytometry of the particles found the highest cell viability to be associated with the low concentrations of $\mathrm{FeSO}_{4} \mathrm{NPs}$, i.e. 1.57 and $3.125 \mathrm{mM} / \mathrm{mL}$ (Figures 3 and 4). Therefore, the effect of NPs was more than the bulk particles on the HT29 cells.

\section{Histopathological Analysis of Rats}

The histopathological examination revealed that there were no pathological changes in intestinal cells. Moreover, hemosiderin pigments were not observed in the small intestine and colon tissues of any of the studied samples (Figure 5).

\section{Discussion}

In the present study, $\mathrm{FeSO}_{4} \mathrm{NPs}$ were synthesized using a planetary ball mill, and the cytotoxicity of the NPs and bulk iron particles to HT-29 cells was examined using the MTT assay. The effects of different doses of these particles were also studied on the intestine of the rats fed by bread enriched with these particles. The results showed that the viable cells decreased in groups treated with bulk and NPs of iron, but necrosis and apoptosis in cell lines were more in the bulk iron treatment groups than iron NPs.

In 2014, Sahu et al investigated the cytotoxic potential
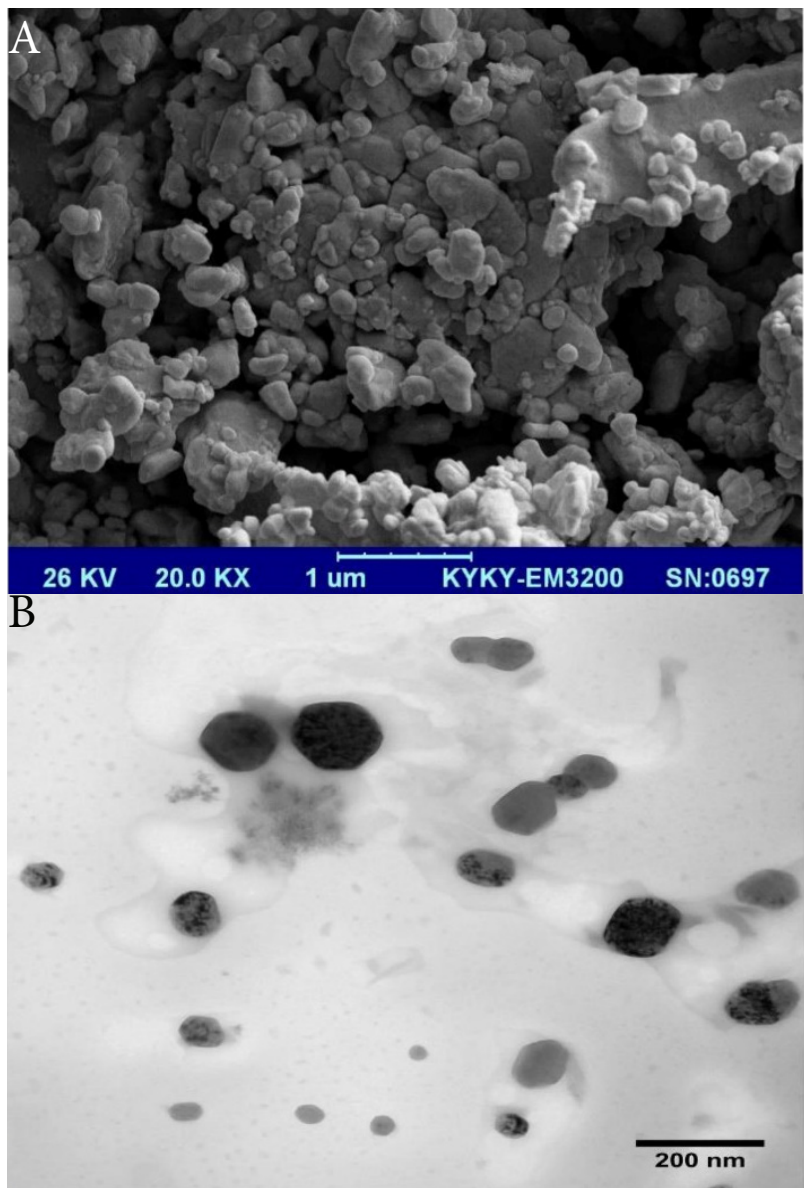

Figure 1. SEM image (A) and TEM image of $\mathrm{FeSO}_{4} \mathrm{NPs}$ (B). 
A

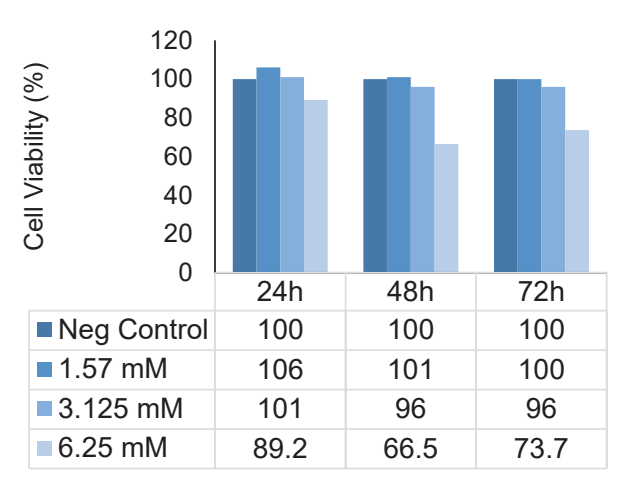

B

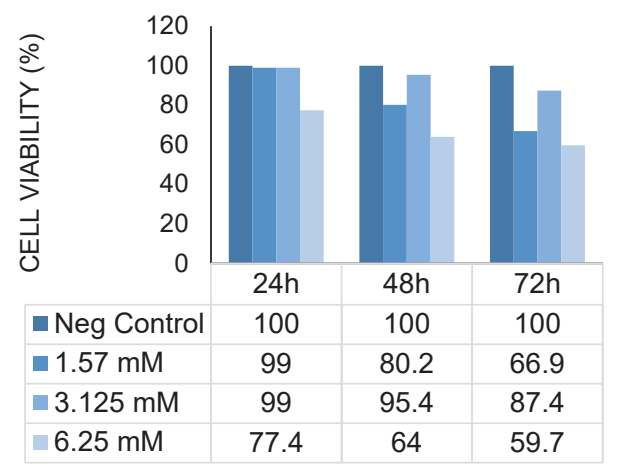

Figure 2. In vitro cell viability assessment of (A) $\mathrm{FeSO}_{4}$-bulk and (B) $\mathrm{FeSO}_{4}$-NPs on HT-29 cells after $24,48,72 \mathrm{~h}$ by MTT assay. of silver NPs (20 nm in diameter) by studying HepG2 and the human intestinal HT-29 cell line. They found these cell lines to be always a good model for evaluating the toxicity of different materials to cells (32). A dose-dependent viability reduction was observed for 72 hours in HT-29 cells compared to the control group at concentrations of 3.125 and 6.25 of the bulk iron. Zödl et al also observed reductions in the signal in the MTT assay at $1.5 \mathrm{mM} /$ $\mathrm{mL}$ of $\mathrm{FeSO}_{4}$ and an associated reduction in the viability of HT-29 cells compared to $\mathrm{FeCl}_{3}$ (34). These results are in agreement with the results of the present study, as cell viability decreases with increasing concentration of NPs. The flow cytometry showed that the concentrations 3.125 and $6.25 \mathrm{mM} / \mathrm{mL}$ of the bulk iron increase necrosis in intestinal cells after $24 \mathrm{~h}$ compared to the Fe NPs. Meanwhile, the viability of cells ultimately decreased at all the concentrations of Fe NPs by increasing the incubation duration to $72 \mathrm{~h}$. The same results were reported by Böhmert et al in 2012, and they found the strong cytotoxic effects of silver NPs on the proliferation and differentiation of HT-29 cells to increase with an increase in the dose and duration of incubation and a decrease in the particle size. Cytotoxicity of the NPs began with causing morphological changes and reducing the cell binding capacity, leading to apoptosis within 24-48 h of exposure (42).

In 2013, Yang et al examined the toxicity of silica NPs
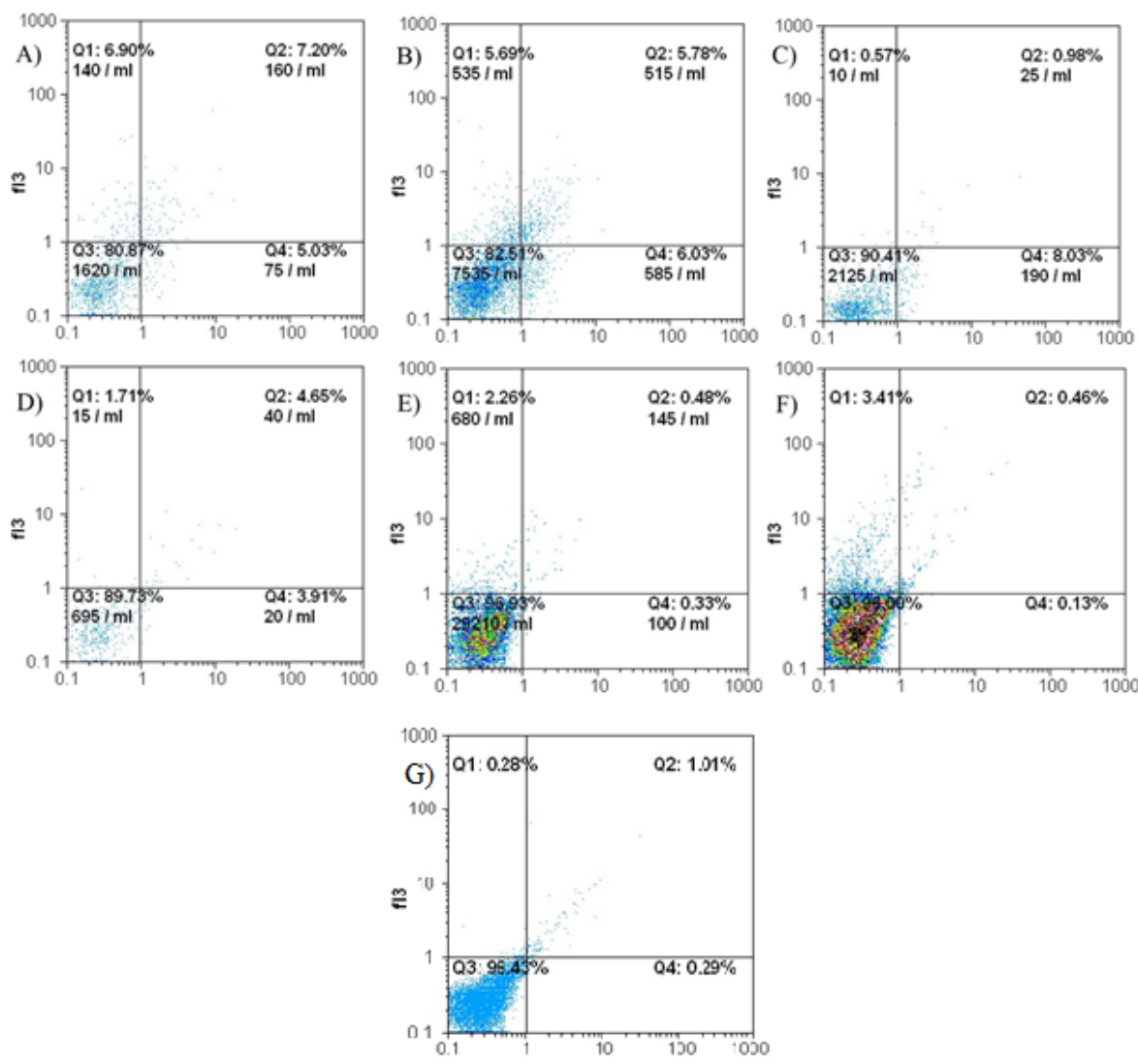

Figure 3. Dot plots of the HT-29 cells apoptotic events induced by $\mathrm{FeSO}_{4}$ particles after $24 \mathrm{~h}$ treatment with: (A, B, C: FeSO4-bulk, 6.25, 3.125, $1.56 \mathrm{mM} / \mathrm{mL}$ respectively; D, E, F: FeS04-NPs, $6.25,3.125,1.56 \mathrm{mM} / \mathrm{mL}$ respectively, and G: Ctrl), where: where Q4: early apoptotic cells, Q3: viable cells, Q2: late apoptotic cells and Q1: necrotic cells. 


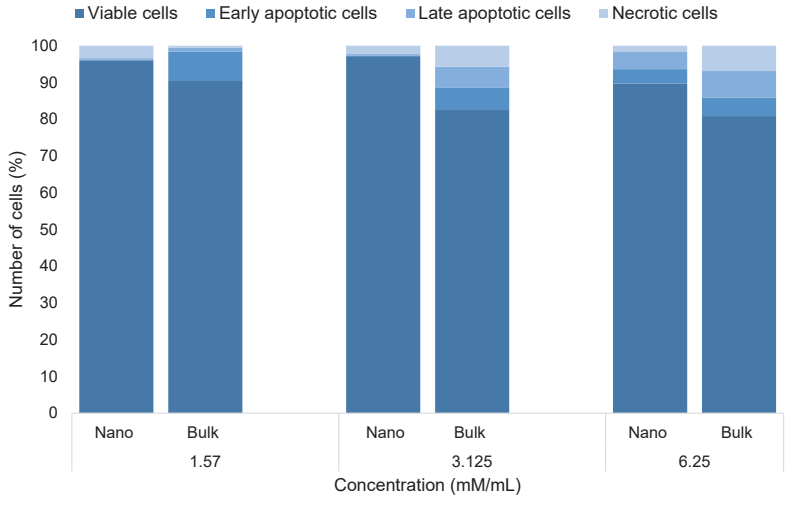

Figure 4. The percentage of HT-29 in terms of living, early apoptotic, late apoptotic, and necrotic cells

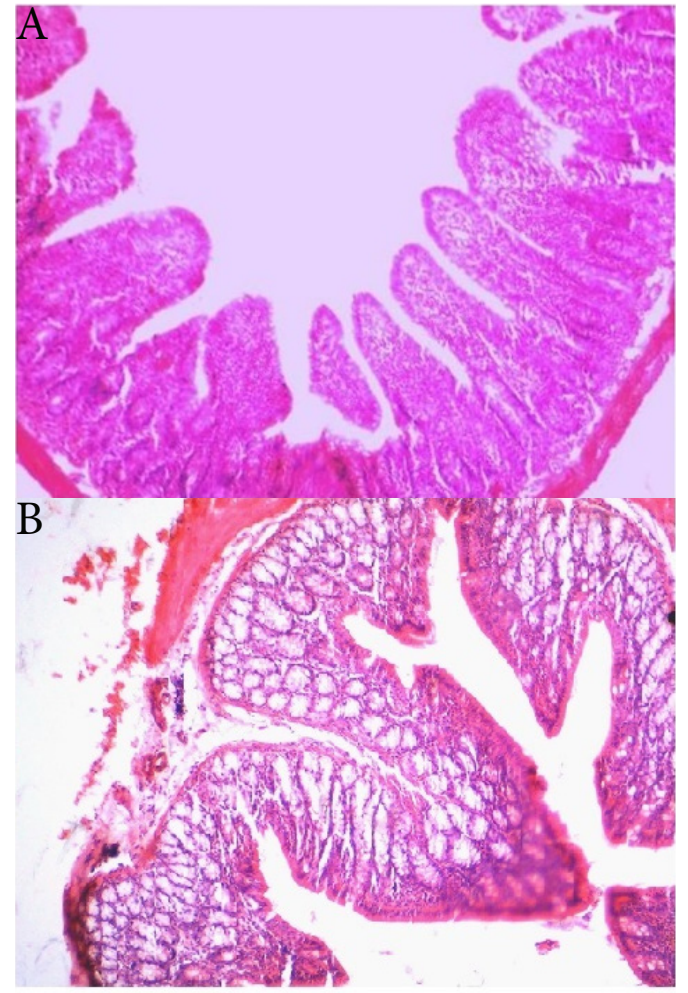

Figure 5. No pathologic lesion was observed in the rat's small intestine (A) and colon (B) (H\&E staining, 40X).

as a food additive to cells in the gastrointestinal tract, namely GES1 and HT-29. They produced silica NPs with a maximum concentration of $100 \mu \mathrm{g}$ and reported that there were no harmful effects on cells in the gastrointestinal tract within 72 hours of exposure. But the concentration of at least $200 \mu \mathrm{g}$ showed the significant adverse effects on cells within $48 \mathrm{~h}$ of exposure. Although these NPs do not cause morphological changes in the cells and do not induce apoptosis and necrosis, they can stop the cell cycle and inhibit the cell growth by entering cells (19).

\section{Conclusion}

The synthesized iron NPs had adverse effects on the HT-29 cancer cells, which intensified by time passage. Contrary to the bulk particles, NPs induced more necrosis in HT-29 cells at the lowest level $(1.57 \mathrm{mM} / \mathrm{mL})$. Noteworthily, the orally iron particles as a bread fortificant in rats did not provoke histopathological lesions in normal intestinal tissue. Since the iron NPs fortified bread had no detrimental effect on the rats' normal intestinal cells, we suggest to study the interaction of iron with bread constituents at a molecular level.

Conflict of Interests

The authors have no conflict of interests in this study.

\section{Ethical Approval}

The project underwent ethical review and was approved by the Institutional Animal Care and Use Committee (approval ID:: IR.UK. VETMED.REC.1398.006).

Authors Contribution

$\mathrm{MB}$; Contributed to conception and design, responsible for overall supervision, Drafted revised and submitted manuscript., EM; Contributed to all experimental works, and interpretation of data. $\mathrm{HE}$; supervision of food analysis, Date analysis, . IK; Supervision of histopathological studies., NA; supervision of cell culture studies, All authors read and approved the final manuscript.

\section{Funding/Support}

This study supported by research deputy of Shahrekord University.

\section{Acknowledgments}

This project was supported by Iran National Science Foundation (INSF) under a grant (No.96002034). We thank Dr. S.Y. Ebrahimipour for his technical assistance and Mr. Ahmadi, pathology lab's expert.

References

1. Borm PJ, Robbins D, Haubold S, Kuhlbusch T, Fissan H, Donaldson $\mathrm{K}$, et al. The potential risks of nanomaterials: a review carried out for ECETOC. Part Fibre Toxicol. 2006;3:11. doi: 10.1186/1743-8977-3-11.

2. Buzea C, Pacheco II, Robbie K. Nanomaterials and nanoparticles: sources and toxicity. Biointerphases. 2007;2(4):MR17-71. doi: 10.1116/1.2815690.

3. Elder A, Gelein R, Silva V, Feikert T, Opanashuk L, Carter J, et al. Translocation of inhaled ultrafine manganese oxide particles to the central nervous system. Environ Health Perspect. 2006;114(8):1172-8. doi: 10.1289/ehp.9030.

4. Gwinn MR, Vallyathan V. Nanoparticles: health effects--pros and cons. Environ Health Perspect. 2006;114(12):1818-25. doi: 10.1289/ehp.8871.

5. Hussain SM, Braydich-Stolle LK, Schrand AM, Murdock RC, Yu KO, Mattie DM, et al. Toxicity evaluation for safe use of nanomaterials: recent achievements and technical challenges. Adv Mater. 2009;21(16):1549-59. doi: 10.1002/ adma.200801395.

6. Hydzik P. [Risks associated with nanotechnology based on European Union legislation]. Przegl Lek. 2012;69(8):490-1.

7. Morris VJ. Emerging roles of engineered nanomaterials in the food industry. Trends Biotechnol. 2011;29(10):509-16. doi: 10.1016/j.tibtech.2011.04.010.

8. Nel A, Xia T, Mädler L, Li N. Toxic potential of materials at the nanolevel. Science. 2006;311(5761):622-7. doi: 10.1126/ science.1114397.

9. Oravecz K, Kalka D, Jeney F, Cantz M, Zs-Nagy I. Hydroxyl free radicals induce cell differentiation in SK-N-MC neuroblastoma cells. Tissue Cell. 2002;34(1):33-8. doi: 
10.1054/tice.2001.0221.

10. Rashidi L, Khosravi-Darani K. The applications of nanotechnology in food industry. Crit Rev Food Sci Nutr. 2011;51(8):723-30. doi: 10.1080/10408391003785417.

11. Singh N, Manshian B, Jenkins GJ, Griffiths SM, Williams PM, Maffeis TG, et al. NanoGenotoxicology: the DNA damaging potential of engineered nanomaterials. Biomaterials. 2009;30(23-24):3891-914. doi: 10.1016/j. biomaterials.2009.04.009.

12. Zaboli KH, Aliarabi H, Bahari AA, Abbas Alipour Kabireh R. Role of dietary nano-zinc oxide on growth performance and blood levels of mineral: a study on in Iranian Angora (Markhoz) goat kids. Journal of Pharmaceutical \& Health Sciences. 2013;2(1):19-26. [Persian].

13. Lin $W$, Huang $Y W$, Zhou XD, Ma Y. In vitro toxicity of silica nanoparticles in human lung cancer cells. Toxicol Appl Pharmacol. 2006;217(3):252-9. doi: 10.1016/j. taap.2006.10.004.

14. Lison D, Thomassen LC, Rabolli V, Gonzalez L, Napierska D, Seo JW, et al. Nominal and effective dosimetry of silica nanoparticles in cytotoxicity assays. Toxicol Sci. 2008;104(1):155-62. doi: 10.1093/toxsci/kfn072.

15. Napierska D, Thomassen LC, Rabolli V, Lison D, Gonzalez $\mathrm{L}$, Kirsch-Volders $M$, et al. Size-dependent cytotoxicity of monodisperse silica nanoparticles in human endothelial cells. Small. 2009;5(7):846-53. doi: 10.1002/smll.200800461.

16. Kong B, Seog JH, Graham LM, Lee SB. Experimental considerations on the cytotoxicity of nanoparticles. Nanomedicine (Lond). 2011;6(5):929-41. doi: 10.2217/ nnm.11.77.

17. Bakand S, Farshad AA. A review of nanotechnology and nanotoxicology. Iran Occup Health. 2007;4(1):1-3. [Persian].

18. Kaluza S, Balderhaar JK, Orthen B, Honnert B, Jankowska E, Pietrowski $\mathrm{P}$, et al. Workplace Exposure to Nanoparticles. Spain: European Agency for Safety and Health at Work (EUOSHA); 2009.

19. Yang YX, Song ZM, Cheng B, Xiang K, Chen XX, Liu JH, et al. Evaluation of the toxicity of food additive silica nanoparticles on gastrointestinal cells. J Appl Toxicol. 2014;34(4):424-35. doi: 10.1002/jat.2962.

20. Dary O, Hurrell R. Guidelines on Food Fortification with Micronutrients. Geneva, Switzerland: World Health Organization, Food and Agricultural Organization of the United Nations; 2006.

21. Scholl TO, Hediger ML, Fischer RL, Shearer JW. Anemia vs iron deficiency: increased risk of preterm delivery in a prospective study. Am J Clin Nutr. 1992;55(5):985-8. doi: 10.1093/ajcn/55.5.985.

22. Scholl TO, Reilly T. Anemia, iron and pregnancy outcome. J Nutr. 2000;130(2S Suppl):443S-7S. doi: 10.1093/ jn/130.2.443S.

23. World Health Organization (WHO). Nutrition for Health and Development: A Global Agenda for Combating Malnutrition. Geneva: WHO; 2000.

24. Mehta AB, Hoffbrand AV. Hematology at a Glance. London: Wiley-Blackwell; 2013.

25. Hosny KM, Banjar ZM, Hariri AH, Hassan AH. Solid lipid nanoparticles loaded with iron to overcome barriers for treatment of iron deficiency anemia. Drug Des Devel Ther. 2015;9:313-20. doi: 10.2147/dddt.s77702.
26. Martínez-Navarrete N, Camacho MM, Martínez-Lahuerta J, Martínez-Monzó J, Fito P. Iron deficiency and iron fortified foods-a review. Food Res Int. 2002;35(2-3):225-31. doi: 10.1016/s0963-9969(01)00189-2.

27. Hansen M, Bæch SB, Thomsen AD, Tetens I, Sandström B. Long-term intake of iron fortified wholemeal rye bread appears to benefit iron status of young women. J Cereal Sci. 2005;42(2):165-71. doi: 10.1016/j.jcs.2005.04.001.

28. Huma N, Salim Ur R, Anjum FM, Murtaza MA, Sheikh MA. Food fortification strategy--preventing iron deficiency anemia: a review. Crit Rev Food Sci Nutr. 2007;47(3):259-65. doi: 10.1080/10408390600698262.

29. Johnson Q, Manner V, Ranum P. Fortification Handbook. The Micronutrient Initiative; 2004

30. Olivares M, Pizarro F, López de Romaña D. Effect of zinc sulfate fortificant on iron absorption from low extraction wheat flour co-fortified with ferrous sulfate. Biol Trace Elem Res. 2013;151(3):471-5. doi: 10.1007/s12011-012-9582-7.

31. Torabian S, Zahedi M, Khoshgoftar AH. Effects of foliar spray of nano-particles of $\mathrm{FeSO} 4$ on the growth and ion content of sunflower under saline condition. J Plant Nutr. 2017;40(5):61523. doi: 10.1080/01904167.2016.1240187.

32. Sahu SC, Zheng J, Graham L, Chen L, Ihrie J, Yourick JJ, et al. Comparative cytotoxicity of nanosilver in human liver HepG2 and colon Caco2 cells in culture. J Appl Toxicol. 2014;34(11):1155-66. doi: 10.1002/jat.2994.

33. Zarei O, Yaghoobi MM. Cytotoxic and anti-proliferative effects of Rosa beggeriana Schrenk extracts on human liver and breast cancer cells. Avicenna J Phytomed. 2019;9(4):386-95.

34. Zödl B, Zeiner M, Paukovits P, Steffan I, Marktl W, Ekmekcioglu C. Iron uptake and toxicity in Caco-2 cells. Microchem J. 2005;79(1-2):393-7. doi: 10.1016/j.microc.2004.10.019.

35. He WL, Feng Y, Li XL, Wei YY, Yang XE. Availability and toxicity of $\mathrm{Fe}(\mathrm{II})$ and $\mathrm{Fe}(\mathrm{III})$ in Caco-2 cells. J Zhejiang Univ Sci B. 2008;9(9):707-12. doi: 10.1631/jzus.B0820023.

36. Bahuguna A, Khan I, Bajpai VK, Kang SC. MTT assay to evaluate the cytotoxic potential of a drug. Bangladesh J Pharmacol. 2017;12(2):115-8.

37. Tabibian M, Sadeghi M, Mohtadinia J, Babashahi M, Mirlohi M. Determination of vitamin D3 in fortified Iranian flat bread (Taftoon) using high-performance liquid chromatography. Nutr Food Sci Res. 2018;5(1):47-54. doi: 10.29252/nfsr.5.1.47.

38. Vieyra-Reyes $P$, Millán-Aldaco $D$, Palomero-Rivero $M$, Jiménez-Garcés C, Hernández-González M, CaballeroVillarraso J. An iron-deficient diet during development induces oxidative stress in relation to age and gender in Wistar rats. J Physiol Biochem. 2017;73(1):99-110. doi: 10.1007/s13105016-0529-x.

39. Mahan LK, Raymond JL. Krause's Food \& the Nutrition Care Process. USA: Sounders Pub; 2016. p. 637.

40. World Health Organization (WHO). Recommendations on Wheat and Maize Flour Fortification Meeting Report: Interim Consensus Statement. WHO; 2009.

41. Shah BG, Belonje B. Bioassay for Iron Source Additives. Can Inst Food Technol J. 1973;6(1):37-40. doi: 10.1016/s03155463(73)73963-8.

42. Böhmert L, Niemann B, Thünemann AF, Lampen A. Cytotoxicity of peptide-coated silver nanoparticles on the human intestinal cell line Caco-2. Arch Toxicol. 2012;86(7):1107-15. doi: 10.1007/s00204-012-0840-4. 